7. Reprod. Fert. (1971) 24, 19-27

\title{
THE SEASONAL NATURE OF REPRODUCTIVE PHENOMENA IN THE SHEEP
}

\author{
II. VARIATION IN FERTILITY FOLLOWING \\ SYNCHRONIZATION OF OESTRUS
}

\author{
T. J. ROBINSON \\ Department of Animal Husbandry, University of Sydney, \\ Sydney, N.S.W. 2006, Australia
}

(Received 23rd December 1969)

\begin{abstract}
Summary. Five tests were conducted at intervals of 3 months to determine the seasonal variation in fertility following treatment with two types of intravaginal sponges impregnated with $30 \mathrm{mg}$ of a synthetic progestagen (SG-9880; Gronolone, Searle). Sponges were prepared with $5 \mathrm{ml}$ ethanol to release $20 \mathrm{mg} \mathrm{SC}-9880$ over a 16 -day period or with $1 \mathrm{ml}$ ethanol to release $10 \mathrm{mg}$. Ewes were inseminated twice, 48 and $64 \mathrm{hr}$ after withdrawal of the sponges.

There was a marked seasonal variation in all parameters associated with fertility and best results were obtained overall with the sponges releasing the higher dose. Treatment in the spring was followed by a low incidence of ovulation, a high incidence of 'silent heats' and few pregnancies following insemination $(13.6 \%)$; most of the ewes that were not pregnant became anoestrous. Treatment in the autumn was followed by a high incidence of ovulation and oestrus, and a high pregnancy rate following a double insemination $(82.5 \%)$, and few animals became anoestrous.
\end{abstract}

\section{INTRODUCTION}

The use of intravaginal sponges impregnated with progestagen for the synchronization of oestrus in the Merino ewe has commonly resulted in conception rates below those initially reported (Robinson, 1965). Known contributory factors are the relative infertility of the semen of individual rams (Robinson, Salamon, Moore \& Smith, 1967), the dose of progestagen impregnated in the sponge (Robinson, Moore, Holst \& Smith, 1967), and the method of impregnation and subsequent amount absorbed (Robinson, Quinlivan \& Baxter, 1968). Field application has shown that the incidence of oestrus following treatment has, on occasions, been low and there have been reports of ewes not cycling after treatment (G. D. Searle and Co., personal communication).

The present experiment was designed to study the seasonal variation in several parameters associated with fertility in the Merino ewe treated with 
intravaginal sponges impregnated with progestagen prepared in such a manner as to provide two different rates of absorption.

The experiment was conducted at the University of Sydney Animal Husbandry Farms, Camden, N.S.W., in 1967-68.

\section{MATERIALS AND METHODS}

\section{Experimental animals}

A total of 271 ewes was used over a 14-month period. They were medium wool Merino ewes, aged 5 to 6 years, purchased through one source in five batches. Oestrus was detected by eight vasectomized rams and semen was obtained from five Merino rams.

\section{Plan of experiment}

The plan is evident from Table 1. In the first four tests, identical treatments were applied in each of the four seasons-autumn (April to May), winter

\section{TABLE 1}

RESPONSE OF EWES TO TREATMENT WITH INTRAVAGINAL SPONGES IMPREGNATED WITH 30 MG SG-9880 IN 1 OR 5 ML ETHANOL AT FOUR SEASONS OF THE YEAR

\begin{tabular}{|c|c|c|c|c|c|c|c|c|}
\hline \multirow{2}{*}{ Season } & \multirow{2}{*}{$\begin{array}{l}\text { Ewes } \\
\text { treated }\end{array}$} & \multicolumn{4}{|c|}{ Response following treatment } & \multicolumn{3}{|c|}{$\begin{array}{l}\text { Observations at slaughter } \\
21 \text { days }\end{array}$} \\
\hline & & $\underset{1}{\text { Ovulated }}$ & $\begin{array}{l}\text { Oestrus } \\
\quad 2\end{array}$ & $\begin{array}{l}\text { 'Silent' } \\
\mathbf{3}\end{array}$ & $\begin{array}{c}\text { Anovular } \\
4\end{array}$ & $\begin{array}{c}\text { Pregnant } \\
5\end{array}$ & $\underset{6}{\text { Cyclic }}$ & $\begin{array}{c}\text { Anoestrous } \\
7\end{array}$ \\
\hline $\begin{array}{l}\text { 1. Autumn } \\
1 \mathrm{ml} \\
5 \mathrm{ml}\end{array}$ & $\begin{array}{l}31 \\
30\end{array}$ & $\begin{array}{l}30 \\
30\end{array}$ & $\begin{array}{l}28 \\
30\end{array}$ & $\begin{array}{l}2 \\
0\end{array}$ & $\begin{array}{l}1 \\
0\end{array}$ & $\begin{array}{l}18 \\
25\end{array}$ & $\begin{array}{r}12 \\
5\end{array}$ & $\begin{array}{l}1 \\
0\end{array}$ \\
\hline $\begin{array}{l}\text { 2. Winter } \\
1 \mathrm{ml} \\
5 \mathrm{ml}\end{array}$ & $\begin{array}{l}30 \\
30\end{array}$ & $\begin{array}{l}27 \\
30\end{array}$ & $\begin{array}{l}24 \\
27\end{array}$ & $\begin{array}{l}3 \\
3\end{array}$ & $\begin{array}{l}3 \\
0\end{array}$ & $\begin{array}{l}13 \\
20\end{array}$ & $\begin{array}{l}6 \\
3\end{array}$ & $\begin{array}{r}11 \\
7\end{array}$ \\
\hline $\begin{array}{l}\text { 3. Spring } \\
1 \mathrm{ml} \\
5 \mathrm{ml}\end{array}$ & $\begin{array}{l}29 \\
30\end{array}$ & $\begin{array}{l}13 \\
16\end{array}$ & $\begin{array}{l}7 \\
8\end{array}$ & $\begin{array}{l}6 \\
8\end{array}$ & $\begin{array}{l}16 \\
14\end{array}$ & $\begin{array}{l}4 \\
4\end{array}$ & $\begin{array}{l}0 \\
1\end{array}$ & $\begin{array}{l}25 \\
25\end{array}$ \\
\hline $\begin{array}{l}\text { 4. Summer } \\
1 \mathrm{ml} \\
5 \mathrm{ml}\end{array}$ & $\begin{array}{l}29 \\
29\end{array}$ & $\begin{array}{l}27 \\
29\end{array}$ & $\begin{array}{l}16 \\
20\end{array}$ & $\begin{array}{r}11 \\
9\end{array}$ & $\begin{array}{l}2 \\
0\end{array}$ & $\begin{array}{l}10 \\
15\end{array}$ & $\begin{array}{l}18 \\
13\end{array}$ & $\begin{array}{l}1 \\
1\end{array}$ \\
\hline $\begin{array}{l}\text { 5. Autumn } \\
5 \mathrm{ml}\end{array}$ & 33 & 33 & 30 & 3 & 0 & 27 & 6 & 0 \\
\hline Totals & 271 & 235 & 190 & 45 & 36 & 136 & 64 & 71 \\
\hline
\end{tabular}

All ewes inseminated twice, 48 and $64 \mathrm{hr}$ after cessation of treatment.

(July to August), spring (October to November), and summer (January to February). The available ewes were divided into two groups, and treated with intravaginal sponges which released progestagen at a relatively fast or at a slow rate. A final test was conducted in the following autumn, using the former type of sponges only, in order to overlap the annual cycle. 


\section{Administration of progestagen}

Each ewe was treated with an intravaginal sponge impregnated with $30 \mathrm{mg}$ SG-9880 (Gronolone, Searle) left in situ for 16 days. The method of impregnation used was that described by Robinson (1965) except that the progestagen was dissolved either in $5 \mathrm{ml}$ or $1 \mathrm{ml}$ ethanol in order to provide two degrees of dispersion and hence two rates of absorption. The sponges were inserted at 08.00 to 10.00 hours on Day 0 and withdrawn at 15.00 to 17.00 hours on Day 16.

\section{Estimation of residual progestagen}

All sponges were air dried on withdrawal; each was then extracted and the residual SG-9880 estimated using the method described by Morgan, Lack \& Robinson (1967). Data for residual progestagen were analysed for fifty-two sponges for each of Tests 1 to 4 and for all in Test 5 .

\section{Detection of oestrus}

Eight vasectomized rams fitted with 'Sire-sine' harnesses and crayons were joined with the ewes immediately on withdrawal of the sponges. Ewes were inspected at 07.00 hours and 17.00 hours daily and those in oestrus were recorded. Ewes not in oestrus when inseminated were returned immediately to the vasectomized rams.

\section{Insemination}

Semen was collected from three to five rams and all ejaculates of good initial motility were pooled. Sperm concentrations were estimated in an EEL colorimeter, standardized against haemocytometer counts. The pooled semen was diluted with whole cow's milk which had been heated to and held at 95 to $97^{\circ} \mathrm{C}$ for $10 \mathrm{~min}$. The dilution rate was adjusted to provide $150 \times 10^{6}$ spermatozoa in $0.1 \mathrm{ml}$ of inseminate.

All ewes were inseminated, irrespective of whether or not they were detected in oestrus. Each was inseminated twice, each time with $0.1 \mathrm{ml}$ of freshly diluted semen, at 16.00 to 17.00 hours on the 2 nd and at 08.00 to 09.00 hours on the 3 rd day after withdrawal of the sponge (48 and $64 \mathrm{hr}$ ).

\section{Parameters of fertility}

All ewes were slaughtered 21 days after the first insemination and the reproductive tracts were recovered. The following data were recorded following treatment and at slaughter:

Following treatment. Ewes in oestrus and the time of onset.

At slaughter. Ewes which: (a) ovulated following treatment, and the number of ovulations; (b) did not conceive and either continued to cycle or became anoestrous; (c) were pregnant or had resorbing embryos.

\section{Analysis of data}

Analyses of variance were used for all data, other than times of onset of oestrus, following angular transformation and the correction of 0 and $100 \%$ 
values (Glaringbold, Biggers \& Emmens, 1953). Ghi-square analysis was applied to the distribution of times of onset of oestrus.

\section{RESULTS}

\section{Amount of progestagen absorbed}

The amount of progestagen present before insertion was estimated at $30.7 \pm$ $0.8 \mathrm{mg}$ for the $1-\mathrm{ml}$ and $31.0 \pm 0.9 \mathrm{mg}$ for the $5-\mathrm{ml}$ sponges. The amounts present after 16 days' insertion were $20.8 \pm 3.9 \mathrm{mg}$ and $11.1 \pm 2.9 \mathrm{mg}$ so that the mean amounts absorbed were 10 and $20 \mathrm{mg}$. There was no significant difference between seasons in the amount absorbed and no interaction.

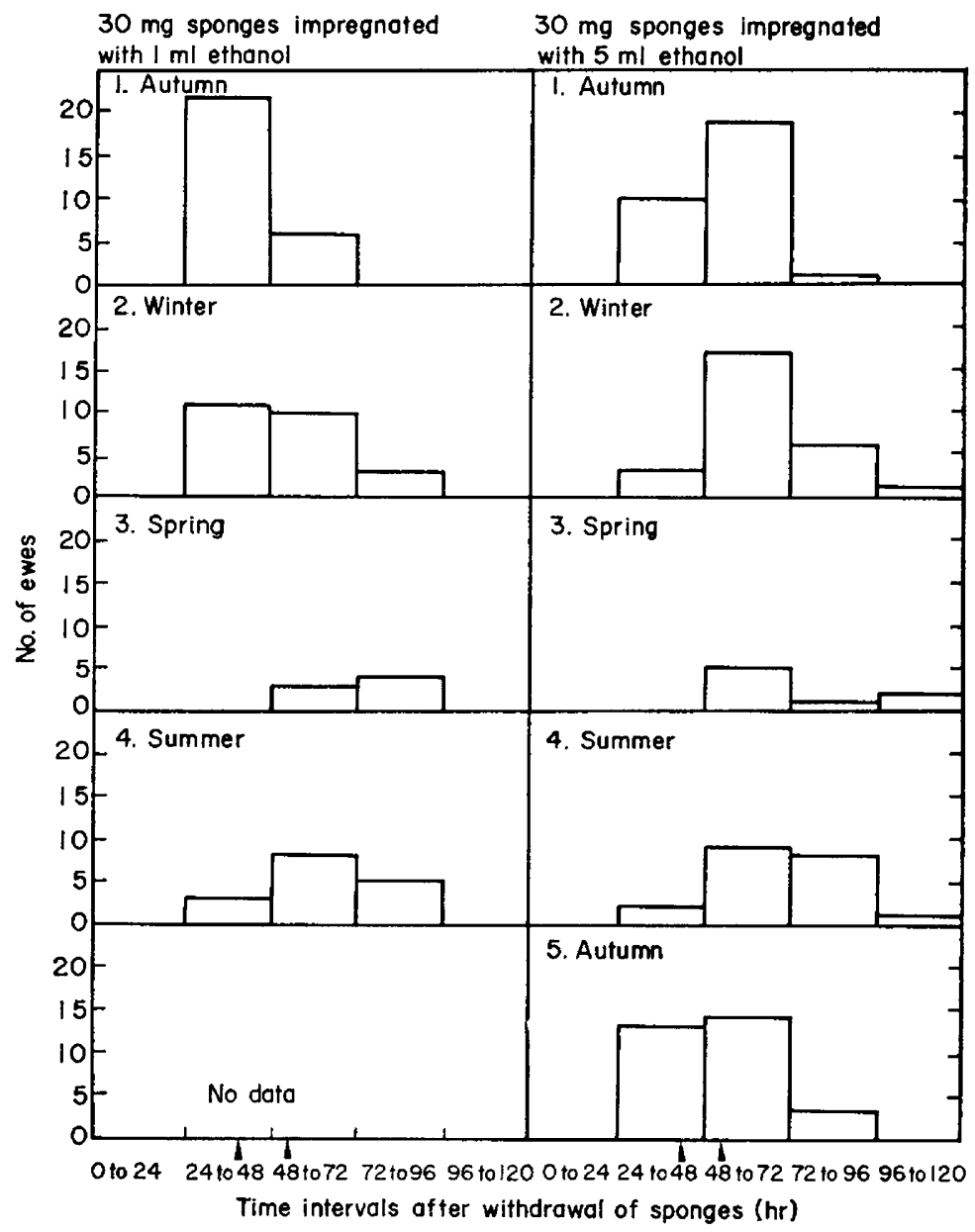

TEXT-FIG. 1. The distribution of time of onset of oestrus in Merino ewes treated with progestagen-impregnated sponges in five successive tests at four seasons of the year. $\uparrow=$ Times of insemination. Significance of interactions between treatments and distribution of time of onset of oestrus: (a) type of sponge $\times$ time: $\chi_{3}^{2}=19.56 ; P<0.001$; (b) season of year $\times$ time: $\chi_{9}^{2}=45.49 ; P<0.001$; (c) type of sponge $\times$ season $\times$ time: $\chi_{9}^{2}=20.62 ; P<$ 0.02 . 
Distribution of time of onset of oestrus

Text-figure 1 shows the highly significant effects of the type of sponge $(P<0.001)$ and the season of the year $(P<0.001)$ on the time of onset of oestrus and the significant interaction $(P<0 \cdot 02)$. Those sponges which released a mean of 10

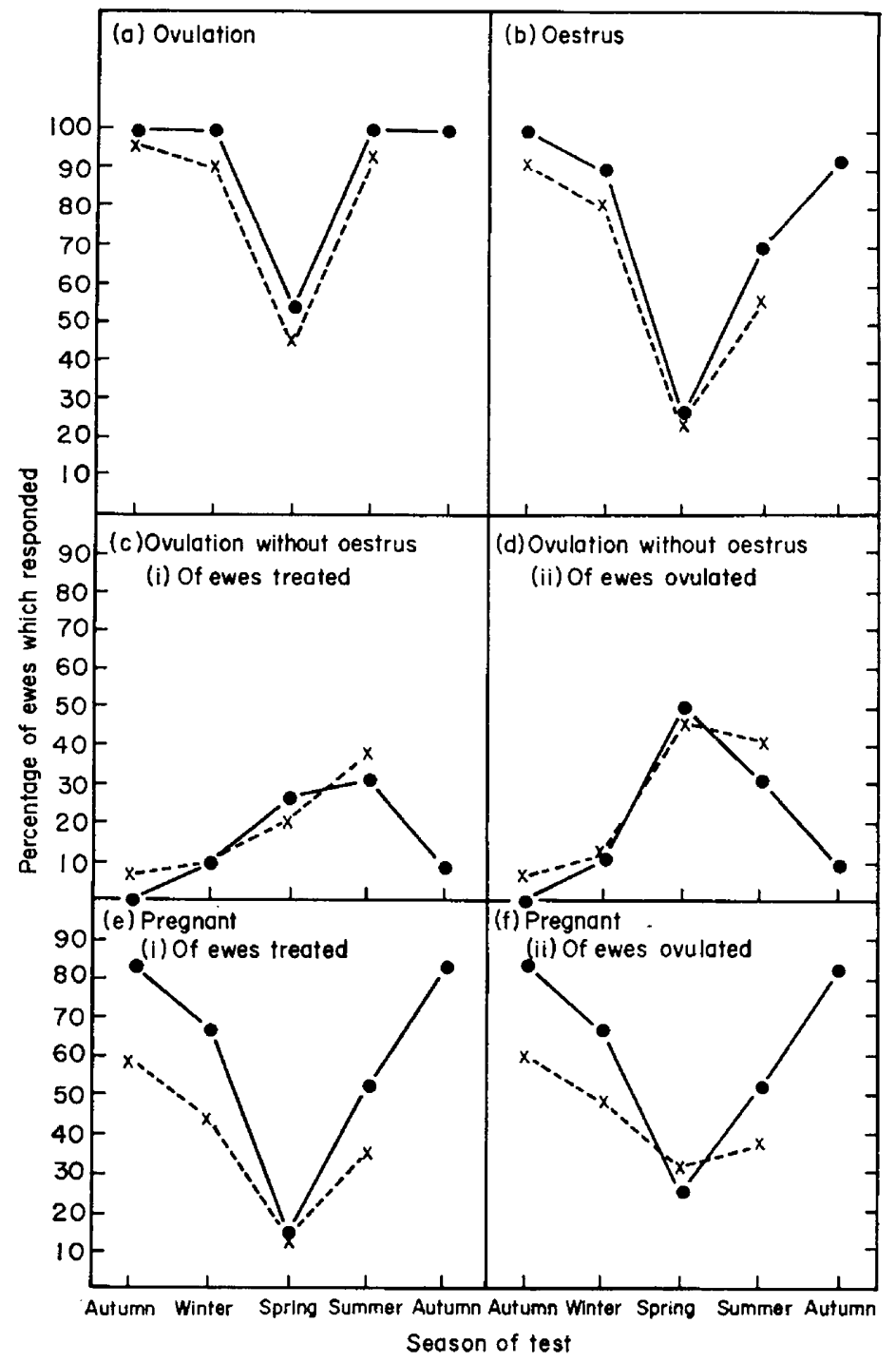

TEXT-FIG. 2. Seasonal changes in several parameters associated with fertility after withdrawal of SC-9880-impregnated intravaginal sponges showing the effect of season (Tests 1 to 5) and of volume of ethanol used for impregnation (Tests I to 4)., $5 \mathrm{ml}$ ethanol (mean absorption 20.0 mg SG-9880); $\times, 1 \mathrm{ml}$ ethanol (mean absorption $10 \mathrm{mg}$ SC-9880).

mg SC-9880 (impregnated with $1 \mathrm{ml}$ ethanol) resulted in an earlier onset of oestrus than did those which released $20 \mathrm{mg}$ (impregnated with $5 \mathrm{ml}$ ). The onset became progressively later from autumn to spring and then became earlier again. The significant interaction was due to the relatively greater 
effect of rate of absorption when reproductive activity was high (autumn and winter) compared to when it was low (spring and summer).

\section{Fertility}

Table 1 presents the data for all parameters studied, and their cyclic nature is illustrated in Text-figs. 2 and 3. Table 2 presents analyses of variance.

There were highly significant $(P<0.001)$ seasonal effects on all parameters studied. Reproductive efficiency following treatment was very high in the autumn, declined dramatically in the spring and then recovered to a peak again in autumn.

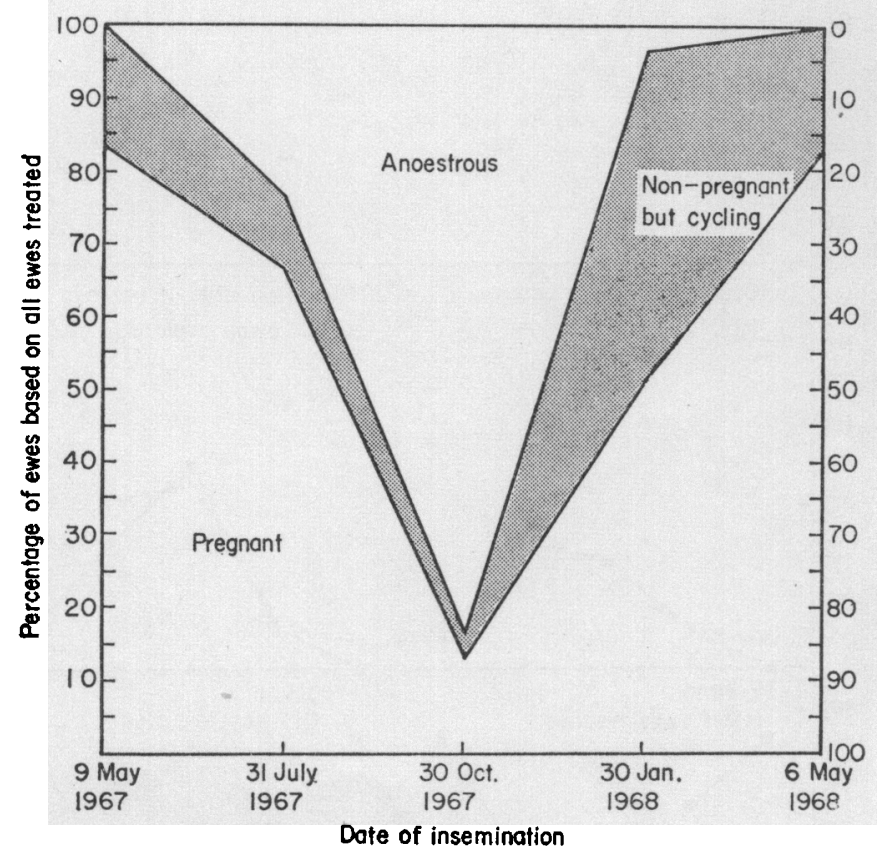

TEXT-FIG. 3. Physiological state of Merino ewes when slaughtered 21 days after insemination at two fixed times after withdrawal of SC-9880-impregnated intravaginal sponges at

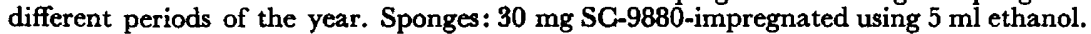
Insemination: twice, at 48 and $64 \mathrm{hr}$ after withdrawal of sponges.

There was a consistent effect of type of sponge (in favour of impregnation with $5 \mathrm{ml}$ ethanol) on the numbers of ewes which ovulated and were in oestrus and which became pregnant.

Ewes which ovulated. The proportion of ewes which ovulated immediately after treatment fell in the spring (thirty of the thirty-six failures) and rose again in the summer and autumn (Text-fig. 2a).

Ewes in oestrus. The proportion of ewes which came into oestrus fell much lower in the spring and recovered much more slowly than did the proportion which ovulated (Text-fig. $2 \mathrm{~b}$ ) so that the incidence of ovulation without oestrus ('silent heats') was higher in the spring and summer than in the autumn and winter (Text-fig. 2c, d). 
Ewes pregnant. The pregnancy rate, based on all ewes treated, declined from 83.3 and $58.1 \%$ (mean $70.5 \%$ ) for the $5-\mathrm{ml}$ and $1-\mathrm{ml}$ sponges used in the autumn to $13.6 \%$ for both types in the spring, and recovered to $81.8 \%$ in the following autumn in which only $5 \mathrm{ml}$ sponges were used.

Ewes anoestrous following treatment. The ovaries of seventy-one ewes which were found to be non-pregnant on slaughter had ceased cyclic function. Of these, thirty-six had not ovulated following treatment and the remaining thirty-five

TABLE 2

ANALYSES OF VARIANCE of DATA IN Column $1,2,3,5$ AND 7 of TABle 1 following ANGULAR TRANSFORMATION

\begin{tabular}{|c|c|c|c|c|c|c|}
\hline \multirow[b]{2}{*}{ Source of variation } & \multirow[b]{2}{*}{ d.f. } & \multicolumn{5}{|c|}{ Mean squares } \\
\hline & & $\begin{array}{c}1 \\
\text { Ewes } \\
\text { ovulated }\end{array}$ & $\begin{array}{c}2 \\
\text { Ewes in } \\
\text { oestrus }\end{array}$ & $\begin{array}{c}3 \\
\text { 'Silent' } \\
\text { oestrus }\end{array}$ & $\begin{array}{c}5 \\
\text { Ewes } \\
\text { pregnant }\end{array}$ & $\begin{array}{c}7 \\
\text { Ewes in } \\
\text { anoestrus }\end{array}$ \\
\hline $\begin{array}{l}\text { A. All data for Tests } \\
1 \text { to } 4 \\
\text { Type of sponge } \\
\text { Season of year } \\
\text { Interaction }\end{array}$ & $\begin{array}{l}1 \\
3 \\
3\end{array}$ & $\begin{array}{c}137 \cdot 8^{*} \\
639 \cdot 1^{* * *} \\
8 \cdot 0\end{array}$ & $\begin{array}{l}120 \cdot 1^{*} \\
870 \cdot 4^{* * *} \\
50 \cdot 6\end{array}$ & $\begin{array}{c}11 \cdot 5 \\
262.7 * * \\
16.9\end{array}$ & $\begin{array}{l}193 \cdot 1^{* *} \\
467 \cdot 1^{* * *} \\
26 \cdot 3\end{array}$ & $\begin{array}{c}31 \cdot 2 \\
1528 \cdot 0^{* * *} \\
17 \cdot 0\end{array}$ \\
\hline $\begin{array}{l}\text { B. Data for } 5 \mathrm{ml} \text { ethano } \\
\text { only, for Tests } 1 \text { to } 5 \\
\text { Season of year } \\
\text { linear } \\
\text { quadratic } \\
\text { cubic } \\
\text { quartic }\end{array}$ & $\begin{array}{l}(4) \\
1 \\
1 \\
1 \\
1\end{array}$ & $\begin{array}{c}0 \cdot 0 \\
415 \cdot 8^{* * *} \\
0 \cdot 0 \\
734 \cdot 4^{* * *}\end{array}$ & $\begin{array}{c}160 \cdot 0^{*} \\
1108 \cdot 9^{* * *} \\
34 \cdot 2 \\
399 \cdot 9^{* * *}\end{array}$ & $\begin{array}{l}161 \cdot 6^{*} \\
338 \cdot 1^{* * *} \\
33 \cdot 9 \\
0.0\end{array}$ & $\begin{array}{l}11 \cdot 4 \\
989 \cdot 5^{* * *} \\
26 \cdot 9 \\
295 \cdot 4^{* *}\end{array}$ & $\begin{array}{c}38 \cdot 8 \\
1605 \cdot 0^{* * *} \\
147 \cdot 5^{*} \\
904 \cdot 3^{* * *}\end{array}$ \\
\hline $\begin{array}{l}\text { Theoretical variance } \\
\qquad(\mathrm{n}=30)\end{array}$ & $\infty$ & $28 \cdot 3$ & $28 \cdot 3$ & $28 \cdot 3$ & $28 \cdot 3$ & $28 \cdot 3$ \\
\hline
\end{tabular}

had ovulated immediately afterwards and then had ceased cyclic activity. This phenomenon was of a highly seasonal nature. In Test 1 (autumn), only one of eighteen (5.6\%) non-pregnant ewes became anoestrous. The incidence of anoestrus increased progressively to eighteen of twenty-seven $(66.7 \%)$ and fifty of fifty-one $(98.0 \%$ ) in Tests 2 and 3 (winter and spring) and then decreased to two of thirty-three $(6.1 \%)$ and none of six $(0.0 \%)$ in Tests 4 and 5 (summer and autumn).

\section{DISCUSSION}

The most striking result of this study is the demonstration of a marked seasonal variation in the response to treatment with progestagens of the Merino ewe, commonly cited as breeding the whole year round (see Asdell, 1964). Lamond (1964) has shown a seasonal variation in sensitivity to progesterone, as measured by the amount required to suppress ovulation, but there appear to be no other data concerning seasonal changes in the several parameters associated with fertility reported upon here. 
It seems that progestagen treatment during the descending phase of the annual breeding cycle (winter-spring) may synchronize anoestrus in the Australian Merino ewe as effectively as it synchronizes oestrus during the ascending phase (summer-autumn). Glearly, Merino ewes are more subject to experiencing an anoestrous period than is commonly accepted. The ability of the anterior pituitary to maintain cyclic ovarian activity is decreasing to such an extent from late winter into spring that the suppressive action of administered progestagen may be enough to stop cyclic activity completely in those ewes which do not become pregnant. As the animals emerge from this period (Textfig. 3), cyclic activity is not inhibited in those ewes which do not become pregnant and, indeed, earlier evidence (Robinson \& Smith, 1967) indicates that it may be stimulated. This seasonality of breeding efficiency is shown by all parameters associated with fertility-the number of ewes which ovulate, which exhibit oestrus and which become pregnant, as well as by the number which become anoestrous.

The high order of significance of the quartic component of the analyses of variance (Table 2, B) shows that the pattern of fall and subsequent rise in the proportions of the experimental ewes which ovulated, exhibited oestrus, and became pregnant (and the rise and subsequent fall in those anoestrous) was more sudden than could be accounted for by a continuous rhythmic process. This suggests that during the critical spring months, although a proportion of Merino ewes in a flock may be exhibiting cyclic ovarian activity, and may continue to conform to a cyclic process if left untouched, this activity may be relatively easy to inhibit by treatment with exogenous progestagen and, once inhibited, will fail to start again spontaneously. This concept is supported by the data for time of onset of oestrus (Text-fig. 1). This showed a marked seasonal rhythm with the time of onset relative to cessation of treatment increasing progressively from autumn to spring and then decreasing.

The method of preparation of the sponges and the consequent amount of progestagen released had a significant effect on ovulation, oestrus and pregnancy. This confirms the previous observation of Robinson et al. (1968) concerning the importance of the release characteristics of the sponges.

Finally, the high conception rates obtained in each of Tests 1 and 5 confirm that potential fertility is high in ewes treated at the peak of their annual cycle of reproductive activity with suitably prepared progestagen-impregnated intravaginal sponges (Robinson, 1965). These ewes were inseminated twice on a fixed time basis after cessation of treatment, and fifty-two of sixty-three ewes $(82.5 \%)$ treated with the better type of sponge were pregnant 3 weeks after insemination. Problems of poor conception rate associated with impaired sperm transport and survival (Quinlivan \& Robinson, 1967, 1969) do exist, but apparently these can be largely overcome, at least in small-scale operations, by a double insemination carried out 48 and $64 \mathrm{hr}$ after cessation of treatment in the autumn months. Treatment in winter will result in a reasonable conception rate but a proportion of the non-pregnant ewes may enter anoestrus. Treatment in the spring is clearly fraught with problems. In previous papers, Robinson et al. (1967) and Robinson \& Moore (1967) reported conception rates approaching $50 \%$ in Merino ewes in the spring and obtained no evidence of non-pregnant 
ewes entering anoestrus. This was rather later in the spring than Test 3 reported here and the ewes, which had been bred in the spring months for generations, were probably past the trough of their annual breeding cycle. The danger period seems to be from winter to early spring when the ewes are entering this trough. From late spring onwards, the proportion of ewes which ovulate and conceive increases and that of non-pregnant ewes which become anoestrous decreases. This process continues until the peak of reproductive activity is reached in the autumn, at which time controlled artificial insemination on a fixed time basis could be a practicable proposition in small flocks where double insemination is feasible.

\section{ACKNOWLEDGMENTS}

This project received financial assistance from grants made by the Australian Research Grants Gommittee and G. D. Searle (Australia) Ltd. Field assistance was rendered by J. Ellsmore, who is supported by the Australian Wool Board. Grateful acknowledgment is made to the management and staff of the Riverstone Meat Works for their co-operation in obtaining the reproductive tracts at slaughter.

\section{REFERENCES}

Asdelt, S. A. (1964) Patterns of mammalian reproduction, 2nd edn. Cornell University Press.

Glaringbold, P. J., Biggers, J. D. \& Emmens, G. W. (1953) The angular transformation in quantal analyses. Biometrics, 9, 467.

LAmond, D. R. (1964) Seasonal changes in the occurrence of oestrus following progesterone suppression of ovarian function in the Merino ewe. F. Reprod. Fert. 8, 101.

Morgan, J., LAcK, R. E. \& Robinson, T. J. (1967) The rate of absorption of SC-9880 from impregnated sponges inserted intravaginally in cyclic crossbred ewes. In: The Control of the Ovarian Cycle in the Sheep. Ed. T. J. Robinson. Sydney University Press.

Quinlivan, T. D. \& Robinson, T. J. (1967) The number of spermatozoa in the Fallopian tubes of ewes at intervals after artificial insemination following withdrawal of SC-9880-impregnated intravaginal sponges. In: The Control of the Ovarian Gycle in the Sheep. Ed. T. J. Robinson. Sydney University Press.

Quinlivan, T. D. \& Robinson, T. J. (1969) Numbers of spermatozoa in the genital tract after artificial insemination of progestagen-treated ewes. F. Reprod. Fert. 19, 73.

Rosinson, T. J. (1965) Use of progestagen-impregnated sponges inserted intravaginally or subcutaneously for the control of the oestrous cycle in the sheep. Nature, Lond. 206, 39.

RoBinson, T. J. \& MOORE, N. W. (1967) The evaluation of progesterone- and SC-9880-impregnated sponges for the synchronization of oestrus for large scale artificial insemination of Merino ewes in spring. In: The Control of the Ovarian Cycle in the Sheep. Ed. T. J. Robinson. Sydney University Press.

Robinson, T. J., Moore, N. W., Holst, P. J. \& Smith, J. F. (1967) The evaluation of several progestagens administered in intravaginal sponges for the synchronization of oestrus in the entire cyclic Merino ewe. In: The Control of the Ovarian Gycle in the Sheep. Ed. T. J. Robinson. Sydney University Press.

Robinson, T. J., Quinlivan, T. D. \& Baxter, G. (1968) The relationship between dose of progestagen and method of preparation of intravaginal sponges on their effectiveness for the control of ovulation in the ewe. 7 . Reprod. Fert. 17, 471.

Robinson, T.J., Salamon, S., Moore, N. W. \& Smith, J. F. (1967) The evaluation of SC-9880-impregnated intravaginal sponges for the synchronization of oestrus for large scale artificial insemination of Merino ewes in summer and autumn. In: The Control of the Ovarian Cycle in the Sheep. Ed. T. J. Robinson. Sydney University Press.

Robinson, T. J. \& SMITH, J. F. (1967) The evaluation of SC-9880-impregnated intravaginal sponges used with or without PMS for the advancement of the breeding season of British ewes. In: The Control of the Ovarian Cycle in the Sheep. Ed. T. J. Robinson. Sydney University Press. 